\title{
Contributing Factors That Affect Perception on Malaysia Property Crowdfunding Initiative
}

\author{
Nurul Faziera Khairul Adlee*, Masnita Misiran \\ School of Quantitative Sciences, Universiti Utara Malaysia, Sintok, Kedah, Malaysia. \\ *Corresponding author. Email: nurulfaziera18@yahoo.com
}

\begin{abstract}
Crowdfunding has risen as a progressive financing model that enables small businesses to raise funds. In Malaysia, an equity crowdfunding platform has extended innovatively into the proposed property crowdfunding initiative tabled in the Budget 2019. This study was conducted to determine the factors that influence Malaysian perception toward property crowdfunding among young adults. The data were collected using a questionnaire. The questionnaires consisted of 30 questions and were distributed to 60 young adult. SAS Enterprise Guide and Statistical Package for Social Sciences (SPSS) were used to analyze the data. As a result, four factors that influence Malaysian perception toward property crowdfunding among young adult were highlighted: risk tolerance, return expectations, saving expectations, and financial knowledge.
\end{abstract}

Keywords: Crowdfunding, Property Crowdfunding, Young Adult, Factor Analysis

\section{INTRODUCTION}

Crowdfunding is a new way of financing. Jeff Howe and Mark Robinson characterized the term crowdfunding in 2005. Howe (2006) described crowdfunding as that act of a company or institution taking an initiative once performed by employees and outsourcing it to a system of individuals as an open call. This activity can be performed either cooperatively or solely by an individual. It was first initiated to utilize the open call group and the big network of potential workers. Brabham (2013) depicted crowdfunding as an online, dispersed critical thinking and production model that uses collective intelligence of online networks for specific purposes put forward by a crowdfunding organization such as the government, a corporation, or volunteers.

In recent years, crowdfunding has risen as a progressive financing model that enables small businesses to raise funds, normally in the beginning stage of their projects, especially those that may somehow struggle to acquire capital (Kuppuswamy \& Bayus, 2013). There are currently four crowdfunding models in accordance with the context and nature of the funding effort (Belleflamme, Lambert \& Schwienbacher, 2014). The first model is based on donations, in which supporters expect no direct return from their donations. The second model is a lending- based where supporters expect a profit rate from their investments in capital. The third model is a rewardbased model in which supporters receive a reward for supporting a project. The reward can be in the form of a loan or a product model. The last model is equity based, where supporters, i.e., investors, and shares of the profits of the project are allocated for the future.

In Malaysia, equity crowdfunding platform has extended innovatively into the proposed property (real estate) crowdfunding initiative tabled in the Budget 2019. Budget 2019 has recognized key priorities to help the change of the Malaysian economy toward a more balanced, sustainable, and comprehensive development through non-conventional crowdfunding activities, particularly in the equity sector through the introduction of its property crowdfunding platform (Securities Commission Malaysia, 2018). Edge Prop (2018) rolled out FundMyHome.com in the quest to solve market inefficiencies elaborated through Property Technology (PropTech), which is a sub-sector of Financial Technology (FinTech). Essentially, FundMyHome acts as an intermediary connecting three parties: the homebuyers, investors, and property developers. In this platform, the property developers offer property for sale via this platform with prices up to RM 500,000. Then, the FundMyHome platform helps facilitate homebuyers to purchase these properties partially funded by investors. 
First-time home buyers are able to buy a house by only paying $20 \%$. The remaining $80 \%$ balance will be funded by investors from participating banks and institutional investors. The investors, in exchange will get a 5\% guaranteed return per annum (p.a.) for five years. Any first-time home customer shall be eligible for the FundMyHome Scheme, among other fundamental criteria. The customer is the legal and beneficial owner of the estate technically based on the system. In addition, customers can purchase a home jointly as long as both are home buyers for the first-time. What seems most exciting is that the purchaser has no refund in the first five years. The buying process is relatively straightforward. Once you have selected your dream home on the completely financed platform, you will be required to pay a $2 \%$ reservation fee. Next, you have to pay the remaining $18 \%$ balance and the associated charges within 14 days. The end-to-end process will take approximately less than 1.5 months. This type of initiative is new and Malaysia is the first country in ASEAN to regulate this framework in 2015. Investors' equity interest will be proportionate to the measure of their investment. The profits will come in capital gains when they eventually sell their stake or if the organization develops to the point where they can begin paying dividends back to their shareholders.

Briefly, this initiative enables first-time homebuyers to own a home or invest in real estate without being subjected to the hassle of conventional financing means (Smart Investor, 2019). First-time homebuyers can enjoy financial alternative, where they are exposed to the property market through smaller investment sums (Khoo, 2018). The integral aim for the progression of this initiative is to encourage home ownership for affordable housing provision and financing targeted for the lower income group (B40 group). This initiative has been perceived both positively and negatively. Whereas the intention seems noble, the crowdfunding platform is critical for its haste and its supposed priority of providing secure, stable homeowners for the first-time homeowners is remarkably short. Although it might be appealing to purchasers to move to RM250,000 for five years immediately on the first glance with only the down payment of RM50,000 or $20 \%$, their rights as an owner are fully realized only if they have paid fully for their property after the first five years (Agora Society Malaysia, 2018). The first-time homeowners who plan to stay on the property for more than five years will be financially deteriorated by the end of the fifth year, since new buyers do not have the full ownership of the property.

The equity crowdfunding market, in particular property crowdfunding, is still young and needs time to develop with huge potential and perceived risk needed to be investigated and understood. Hence, these nonconventional methods of financing are expected to raise perception issue. Such property crowdfunding model is expected to be the most complicated model to sustain with no prior reference from a major economy. There might also be other risks involved, such as the security and sustainability of its portal and platform, outright fraud, and the volatility of the returns of its capital that is vulnerable to current economic performance. Some analysts also compared this model with the United States subprime crisis, as this model allows homeownership among the riskiest group in the country.

\section{PERCEPTION STUDY ON PROPERTY CROWDFUNDING}

Crowdfunding is a developing marvel that has pulled in significant enthusiasm from researchers and specialists alike, chiefly because of its allure as an elective wellspring of subsidizing (Hossain \& Oparaocha, 2017). Equity crowdfunding offers financial specialists a stake in an organization in exchange for funding. Although there are exemptions, these organizations are typically private and not recorded on a trade. Before, these organizations would have sold good offers to attendant financial specialists or investment firms. As equity crowdfunding has developed exponentially, the advantages that accompany this platform are paired with its disadvantages.

The chances for success for such investments in equity-based crowdfunding are increased not only by equity retention but also by providing sufficient information regarding the investment risk. The incentive to invest in crowdfunding immobilization involves low income rates, increased investment possibilities, reduced fee structures, and excellent returns. However, it is important to know what motivates the shareholder to invest in the decisive factor in driving the change. According to Ahlers, asymmetries between crowd founders and investors (Günther, Cumming \& Swiss, 2017) can complicate the investment process for stock crowdfunding since the data on the businesses they invest in are restricted by single investors. Hervé et al. (2016) stated that the incentives of investors, including equity crowdfunding, and real estate crowdfunding, differ from others.

The difference in the guidance and specific organization between countries of equity-based crowdfunding investments may widen the perceived risk. For example, Belleflamme et al. (2014) indicated that European equity is confined to government organizations with rigid regulatory obligations. Returns, however, can be structured as a predetermined sharing of gains. In addition, Agrawal, Catalini and Goldfarb (2015) considered the geographical distance between the investor's location and the crowdfunded project can be another possible challenge. Due to the lack of knowledge about the post-investment situation, risks could also increase, thereby reducing the transparency of the public funding media. In addition, it was noted by 
Borello, Veronica and Pichler (2015) that the primary restriction of crowdfunding is the restricted availability of government data regarding projects seeking financing.

In contrast, considerable attention is given to typical investors in the literature on property investment decision-making. Shiller and Case (1988) investigated, for example, the behavior of the buyer in the residence and after boom markets and qualitatively examined family decision-making and emotions in home buying decisions. MacCowan and Orr (2008) investigated the conduct of assets disposal fund managers' decisionmaking processes. Lowies, Hall and Cloete (2016) examined the heuristic factors that drive the management decisions of listed property funds.

The important changes in investment motive by sex, age, and investor experience regarding estate crowdfunding companies were elucidated by Pearson, Johdet and Näselius (2016). Barber and Odean (2001) showed that, while both males and females are overconfident in investment, males have a stronger expectation that investments will produce beneficial outcomes. Hervé et al. (2016) also recognized the clear majority of shareholders as male funders and most shareholders are under 55. Cholakova and Clarysse (2015) further considered that record investment in capital stock crowdfunding is a beneficial measure of continued investment, which emphasizes its significance as an incentive to invest in this medium. This finding was based on the work of Nicolosi, Peng and Zhu (2009), who found that individuals learn from their investment background and decide on future stock income, in order to make better profits while learning.

Numerous studies have explored property crowdfunding. In this study, the aim was specifically to determine the factors that influence Malaysian perception toward property crowdfunding. Therefore, the objective of the study was to conduct a factor analysis using SAS Enterprise Guide and Statistical Package for Social Sciences (SPSS) and evaluate the result from Malaysian perception toward property crowdfunding among young adult.

\section{METHODOLOGY}

This study was based on a self-administered questionnaire related to the crowdfunding responses of young adults. The primary data for this study were collected from a questionnaire. The sample consisted of respondents 18-35 years old who have been working for 1-5 years. The questionnaires consisted of 30 questions on crowdfunding knowledge and distributed to $60(\mathrm{~N}=$ 60) young adults. The responses toward questionnaire were illustrated in semantic scale of $1-7$, where 1 represents strongly disagree while 7 represents strongly agree. Furthermore, factor analysis technique was used to determine the possible factors, constructs or domains related to the area of investigation. The process involve data reduction and simplification of variables explained in terms of related factors (Leech, Barrett \& Morgan, 2014). In this study, Principle Component Analysis was used to analyze the normally distributed data using SAS Enterprise Guide and SPSS.

\section{FINDINGS AND DISCUSSIONS}

As above, in a broad-based equity strategy that is further emphasized by equity crowdfunding, the literature suggests conflicting results on the three factors financial knowledge, return expectations, and risk tolerance, but, after analysis were run, four new factors were suggested.

Table 1. Correlation matrix table.

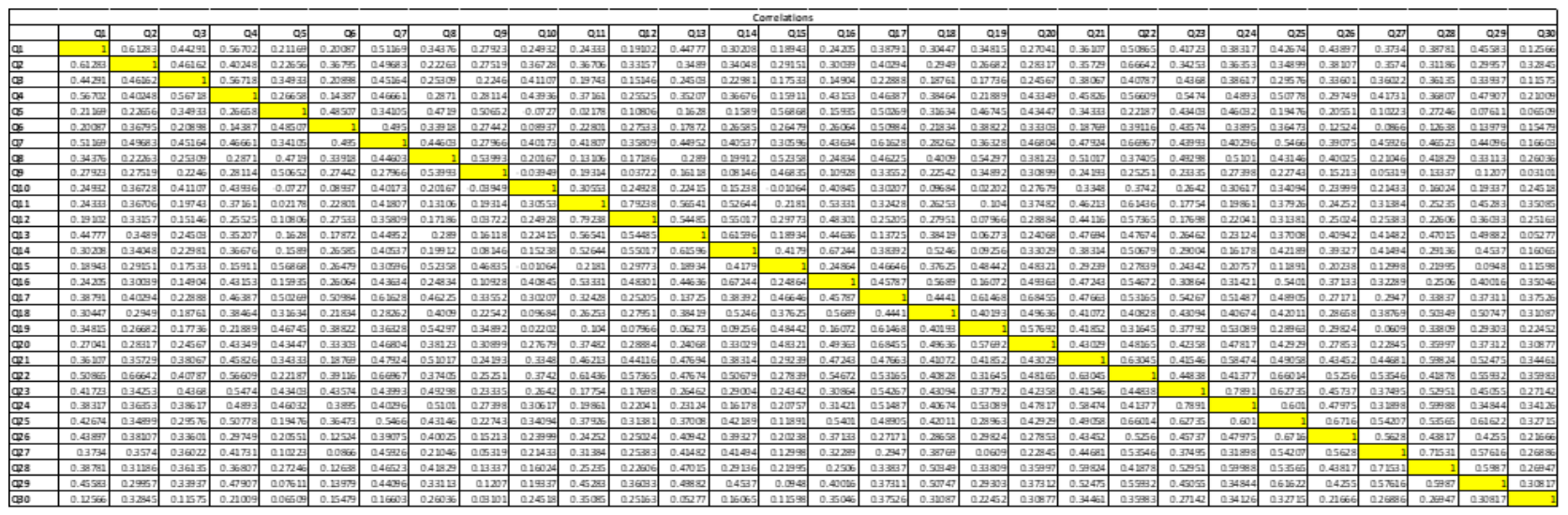

The findings presented in this paper reveal the SAS output of correlation matrix table for 30 variables. Table I shows the correlation coefficient between variables. The pattern of relationship observed. Variables with low correlation coefficient $(r<|0.30|)$ were considered to be removed because of the absence of patterns relationship
(Yong and Pearce, 2013). The correlations among all variables were acceptable. The determinant of correlation matrix indicated that value was greater than 0.00001 , thus the data do not have a problem with multicollinearity 
Table 2. Kaiser's Measure of Sampling Adequacy.

\section{KMO and Bartlett's Test}

Kaiser-Meyer-Olkin Measure of Sampling Adequacy.

Approx. Chi-Square

As shown in Table II, the Kaiser's measure of sampling adequacy used to measure sampling adequacy revealed that the sampling for this study was acceptable with 0.794 . The result is greater than 0.6 , which is considered good enough in KMO (Field, 2005). Therefore, all variables have relationships with each other. The factor analysis is considered as it should be in this study.

Then, as shown in Figure I, six factors were considered after optimizing the factor structure. The inspection of scree plot determined the gradual trailing off (scree) and stop at factor six, which shows the plot curve start to become constant. This is also known as the point of inflexion (Yong and Pearce, 2013). Note that both eigenvalues and scree plot after factoring

\section{Rotation Method: Varimax}

Table 3. Rotated Component Matrix. support the conclusion that the 30 variables can be reduced to six factors in the study.

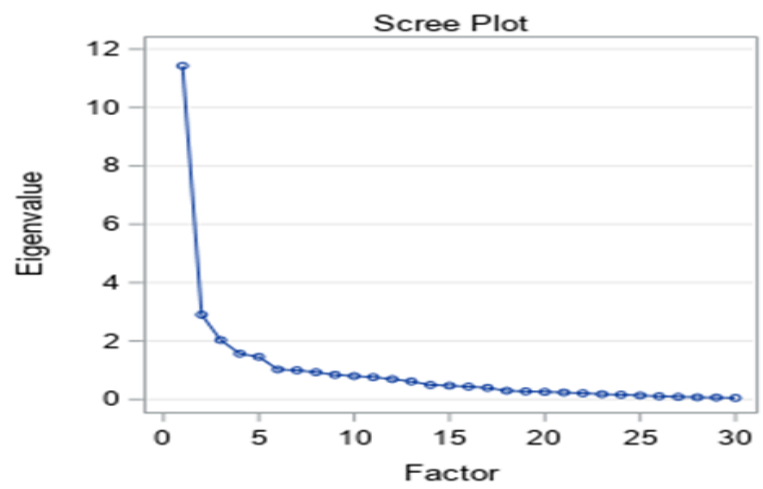

Figure 1 Scree Plot.

\begin{tabular}{|c|c|c|c|c|c|c|}
\hline & Component & & & & & \\
\hline & 1 & 2 & 3 & 4 & 5 & 6 \\
\hline Q28 & .814 & & & & 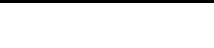 & \\
\hline Q27 & .740 & & & & & \\
\hline Q29 & .667 & & & & & \\
\hline Q26 & .662 & & & & & \\
\hline Q25 & .659 & & & & & \\
\hline Q23 & .568 & & & & & \\
\hline Q24 & .543 & & & & .403 & \\
\hline Q21 & .474 & & & & & \\
\hline Q18 & .458 & & .424 & & & \\
\hline Q12 & & .810 & & & & \\
\hline Q11 & & .799 & & & & \\
\hline Q14 & & .771 & & & & \\
\hline Q13 & .427 & .666 & & & & \\
\hline
\end{tabular}




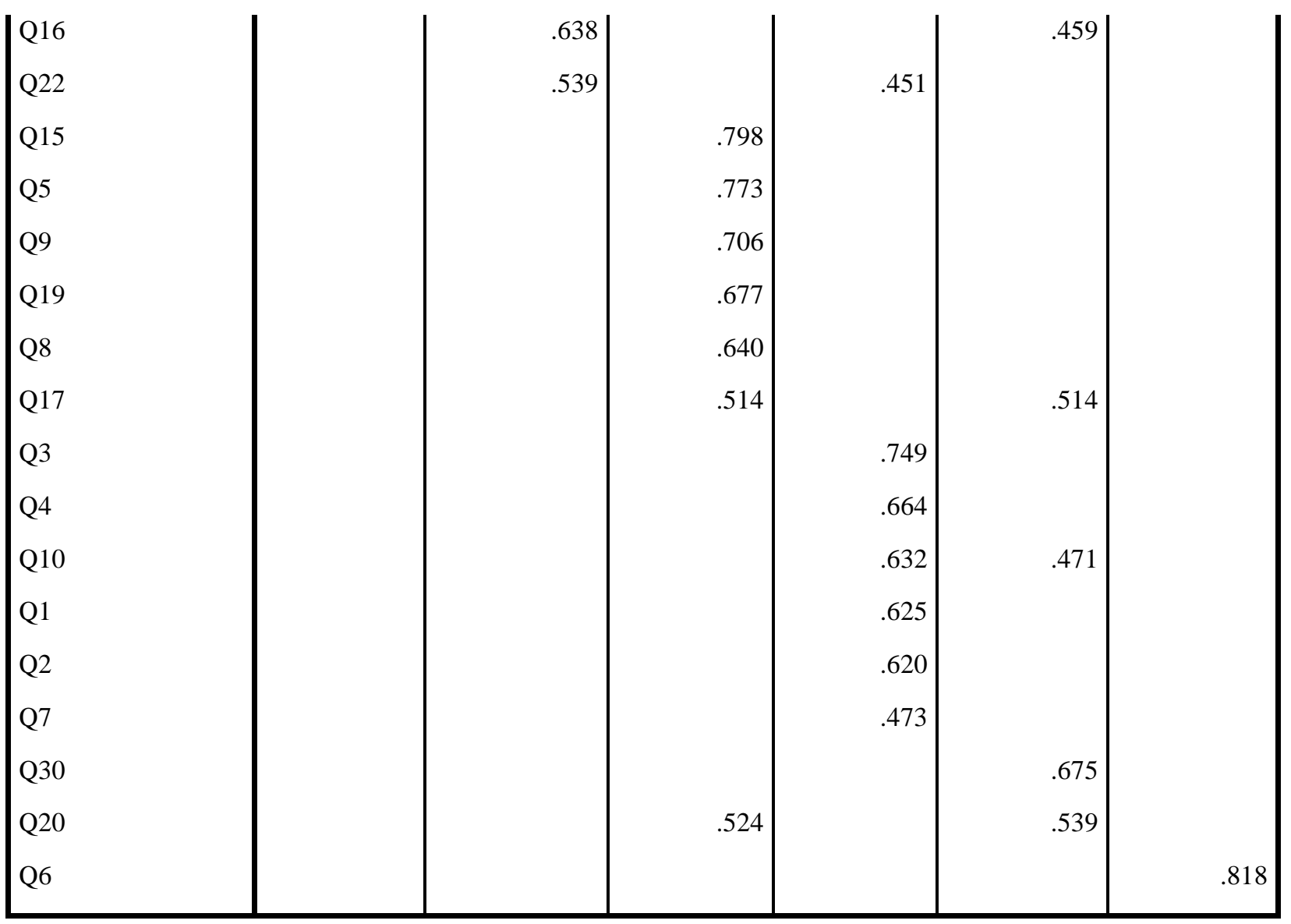

The rotation idea is to reduce the number factor in which the variable being investigated has a high load. The rotation does not necessarily change anything but makes interpretation easier. In Table III, six factors are highlighted. However, after the rotation, the most items are in Factors 1-4.

Table 4. Number of Items.

\begin{tabular}{|l|l|}
\hline Factor & Item \\
\hline Factor 1 & 9 items \\
\hline Factor 2 & 6 items \\
\hline Factor 3 & 6 items \\
\hline Factor 4 & 6 items \\
\hline Factor 5 & 2 item \\
\hline Factor 6 & 1 item \\
\hline
\end{tabular}

Table IV shows the number of items for each factor. Factors 5 and 6 have only two and one items, respectively. Since the items in Factor 5 are similar to those in Factor 1, they can be added into Factor 1. Similarly, the item in Factor 6 is added in Factor 4. Factor 1 refers to risk tolerance, Factor 2 refers to return expectations, Factor 3 refers to saving expectations and Factor 4 refers to financial knowledge. Figure II shows these factors of Malaysian perception on property crowdfunding among young adults.

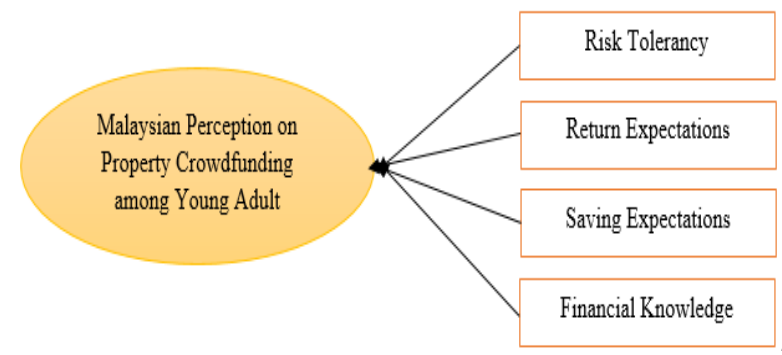

Figure 2 Factors of Malaysian perception on property crowdfunding among young adults.

\section{CONCLUSIONS}

Factor analysis satisfies the requirement of identifying the appropriate number of factors to be produced as well as the similar related elements to determine the appropriate structural items in this study. Data reduction helps the researcher to produce a small number of factors from many variables. This study examined Malaysian perception of property crowdfunding among young adults using 30 variables and then produced six factors after factor analysis. Finally, the findings of factor analysis in this study worth exploring on the basis of the construction emerge 
to know how young adults actually perceive property crowdfunding.

Through this study, the researcher can understand the workable model toward equity crowdfunding of Malaysia setting to attract crowds toward this platform. In addition, the researcher is able to perceive the present issues and discover the challenges involved in equitybased property crowdfunding and after that make innovative recommendations to improve the equitybased property crowdfunding mechanism in Malaysia.

Therefore, this study is important to assist our government with promoting equity-based property crowdfunding as an alternative financing channel that encourages the development of young adults to become first-time homebuyers, which significantly benefits the development of the national economy. It also gives insight for government's next course of action.

\section{ACKNOWLEDGMENTS}

I am grateful to Allah S.W.T for bestowing my courage in completing this project successfully. I am delighted to convey my gratitude to all of the people who help in contributing in different ways in this project.

I have taken effort for this study by contributing my time and energy on completing this study. However, it would not have been possible without the support and assistance from lecturers and experts.

I am highly indebted to my supervisor, Dr. Masnita Misiran for her sharing expertise, valuable guidance, understanding, patience, and encouragement extended to my throughout the duration of the study.

Next, I would like to express my gratitude to all my respondents that involved in this study. I am deeply appreciate their helpfulness and willingness in providing the useful data and information to be conducted for this study.

Last but not least, I also like to pay my regards to my family and friends for the unceasing encouragement, emotional support, and attention during completing this research.

\section{REFERENCES}

[1] Agrawal, A., Catalini, C. and Goldfarb, A. 'Crowdfunding: geography, social networks, and the timing of investment decisions'. Journal of Economics and Management Strategy, 24(2), 253274. https://doi.org/10.1111/jems.12093, 2015.

[2] Ahlers, G. K., Günther, C., Cumming, D. and Schweizer, D. 'Signaling in equity crowdfunding. Research gate'. Retrieved from https://www.researchgate.net/publication/32094464 5_Signaling_in_Equity_Crowdfunding, 2017.

[3] Barber, B. M. and Odean, T. 'Boys will be boys: gender, overconfidence, and common stock Investment'. Quarterly Journal of Economics, 116(1), pp. 261-292. Retrieved from https://faculty.haas.berkeley.edu/odean/papers/gen der/boyswillbeboys.pdf. https://doi.org/10.1162/003355301556400, 2001.

[4] Belleflamme, P., Lambert, T. and Schwienbacher, A. 'Crowdfunding: tapping the right crowd'. Journal of Business Venturing, 29(5), pp. 585-609. Retrieved from https://www.researchgate.net/publication/26377534 1_Crowdfunding_Tapping_the_Right_Crowd. https://doi.org/10.1016/j.jbusvent.2013.07.003, 2014.

[5] Borello, G., Veronica, D. C. and Pichler, F. 'The funding gap and the role of financial return crowdfunding: some evidence From European platforms'. Journal of Internet Banking and Commerce, 20. Retrieved from https://www.researchgate.net/publication/28288973 8_The_Funding_Gap_and_The_Role_of_Financial _Return_Crowdfunding_Some_Evidence_From_E uropean_Platforms, 2015.

[6] Brabham, D. C. 'What is crowdsourcing? Towards an integrated crowdsourcing definition. Retrieved from My crowdsourcing blog'. Retrieved from http://www.crowdsourcing-blog.org/que-es-elcrowdsourcing-definicion-decrowdsourcing/?lang=en, 2013.

[7] Cholakova, M. and Clarysse, B. 'Does the Possibility to make equity investments in crowdfunding projects crowd out reward-based investments?' Entrepreneurship Theory and Practice, 39(1), pp. 145-172. https://doi.org/10.1111/etap.12139, 2015.

[8] Edge-Prop. 'Further clarification from Tong on Crowd Funding and the Budget. Retrieved from EdgeProp Smarter Property Search'. Retrieved from https://www.edgeprop.my/content/1442945/further -clarification-tong-crowd-funding-and-budget, 2018.

[9] Hervé, F., Manthé, E., Sannajust, A. and Schwienbacher, A. 'Investor motivations in investment-based crowdfunding. Semantic scholar'. Retrieved from https://pdfs.semanticscholar.org/801e/808e0910229 93c689084e847ea32db0aefe8.pdf, 2016. 
[10] Hossain, M. and Oparaocha, G. O. 'Crowdfunding: motives, definitions, typology and ethical challenges'. Entrepreneurship Research Journal, 7(2). https://doi.org/10.1515/erj-2015-0045, 2017.

[11] Howe, J. and Robinson, M. 'Crowdsourcing. Retrieved from Wikipedia' The Free encyclopedia. Retrieved from https://en.wikipedia.org/wiki/Crowdsourcing, 2005.

[12] Howe, J. 'What is crowdsourcing? Towards an integrated crowdsourcing definition. Retrieved from My crowdsourcing blog'. Retrieved from http://www.crowdsourcing-blog.org/que-es-elcrowdsourcing-definicion-decrowdsourcing/?lang=en, 2006.

[13] Khoo, N. 'Budget 2019: SC supports use of tech such as property crowdfunding platforms in driving economy. Retrieved from EdgeProp Smarter Property Search'. Retrieved from https://www.edgeprop.my/content/1441111/budget -2019-sc-supports-use-tech-such-propertycrowdfunding-platforms-driving-economy, 2018.

[14] Kuppuswamy, V. and Bayus, B. L. 'Crowdfunding creative ideas: the dynamics of project backers in Kickstarter'. SSRN Electronic Journal, pp. 1-37. Retrieved from https://funginstitute.berkeley.edu/wpcontent/uploads/2013/11/Crowdfunding_Creative_I deas.pdf. https://doi.org/10.2139/ssrn.2234765, 2013.

[15] Leech, N. L., Barrett, K. C. and Morgan, G. A. Exploratory factor analysis and principal components analysis. IBM SPSS for intermediate statistics: use and interpretation, 68-83, 2014.

[16] Lowies, G. A., Hall, J. H. and Cloete, C. E. 'Heuristic-driven bias in property investment decision-making in South Africa'. Journal of Property Investment and Finance, 34(1), pp. 51-67. https://doi.org/10.1108/JPIF-08-2014-0055, 2016.

[17] MacCowan, R. J. and Orr, A. M. 'A behavioural study of the decision processes underpinning disposals by property fund managers'. Journal of Property Investment and Finance, 26(4), pp. 342-
361. https://doi.org/10.1108/14635780810886645, 2008.

[18] Nicolosi, G., Peng, L. and Zhu, N. 'Do individual investors learn from their trade experience?' Journal of Financial Markets, pp. 317-336. Retrieved from https://www.researchgate.net/publication/22283691 3_Do_Individual_Investors_Learn_from_Their_Tr ade_Experience, 2009.

[19] Pearson, A., Johdet, J. and Näselius, M. 'Understanding the Crowd: A quantitative study on investor motivation in equity crowdfunding. Jonkoping International Business School, 65'. Retrieved from http:/hj.divaportal.org/smash/record.jsf?pid=diva2\%3A932955 \&dswid=-5062, 2016.

[20] Securities-Commmission-Malaysia. Annual report 2018: Suruhanjaya Sekuriti. Retrieved from https://www.sc.com.my/api/documentms/download .ashx?id=69b9ad2a-13c7-40bf-b0d3341951a62278, 2018.

[21] Shiller, R. J. and Case, K. E. 'The behavior of home buyers in boom and post-boom markets'. New England Economic Review, pp. 29-46. Retrieved from https://www.nber.org/papers/w2748.pdf, 1988.

[22] Smart-Investor. 'The boon and bane of real estate crowdfunding. Retrieved from Smart Investor'. Retrieved from https://www.smartinvestor.com.my/the-boon-andbane-of-real-estate-crowdfunding/, 2019.

[23] Society-Malaysia,Agora. 'Why the FundMyHome 'property crowdfunding' scheme is bad news. Retrieved from Free Malaysia Today'. Retrieved from

https://www.freemalaysiatoday.com/category/opini on/2018/11/11/why-the-fundmyhome-propertycrowdfunding-scheme-is-bad-news/, 2018.

[24] Young adult (psychology). Retrieved from Wikipedia, the free encyclopedia. Retrieved from https://en.wikipedia.org/wiki/Young_adult_(psycho $\log$ ),

2019 